\title{
PERANAN POLA PENGAIRAN DAN METODE PENGENDALIAN HAMA TIKUS (Rattus argentiventer)TERHADAP PRODUKSI PADI SAWAH (Oryza sativa L.)
}

\author{
Elda Sari Siregar ${ }^{1 *}$, Fery Endang Nasution ${ }^{2 *}$ \\ ${ }^{1 *}$ Fakultas Pertanian Universitas Muhammadiyah Tapanuli Selatan, Sumatera Utara
}

\begin{abstract}
ABSTRAK
Tujuan dari panelitian ini adalah untuk mengetahui produksi padi sawah akibat peranan pola pengairan dan metode pengendalian hama tikus. Penelitian ini dilaksanakan di desa Singali, kecamatan Padangsidimpuan Hutaimbaru, kota Padangsidimpuan, dengan ketinggian tempat lebih kurang dari 500 m diatas permukaan laut. Penelitian ini menggunakan Rancangan Split Plot Desain yang terdiri dari 9 perlakuan dan 3 ulangan dengan Faktor peranan pola pengairan dan metode pengendalian hama tikus, parameter yang diamati adalah tinggi tanaman, intensitas serangan tikus, berat gabah per rumpun dan per plot. Hasil penelitian menunjukkan bahwa pola pengairan menunjukkan pengaruh nyata pada pengamatan intensitas serangan pada umur 9 mst, 10 mst, 11 mst, 12 mst dan 13 mst dan pada pengamatan berat gabah per rumpun dan per plot. Pola pengairan yang menunjukkan pengaruh tidak nyata pada pengamatan tinggi tanaman pada setiap umur pengamatan yaitu 3 mst, 5 mst. Pada perlakuan pola pengairan paling tinggi intensitas serangannya adalah $\mathrm{P}_{3}$ (pengairan berselang). Pada perlakuan metode pengendalian hama tikus menunjukkan pengaruh yang nyata pada pengamatan berat gabah per plot dan intensitas serangan pada semua umur pengamatan mulai dari 9 mst, 10 mst, 11 mst, 12 mst dan 13 mst. Metode pengendalian tikus menunjukkan pengaruh tidak nyata pada pengamatan tinggi tanaman pada setiap umur pengamatan berat gabah per rumpun. Perlakuan metode pengendalian hama tikus yang paling tinggi intensitas serangannya adalah $\mathrm{M}_{2}$ (perangkap). Pada interaksi perlakuan pola pengairan dan metode pengendalian menunjukkan pengaruh tidak nyata pada setiap pengamatan.
\end{abstract}

Kata Kunci : Pengairan, Hama Tikus, Padi 


\section{PENDAHULUAN}

Indonesia merupakan negara agraris dengan luas lahan pertanian jutaan hektar. Beras telah menjadi makanan pokok hampir seluruh penduduknya sehingga produksinya harus diamankan. Ternyata swasembada beras tidak selamanya dapat dipertahankan terbukti masih seringnya negara melakukan impor beras dari Thailand, Vietnam dan Kamboja (Anisa dan Ami, 2011).

Padi merupakan tanaman pangan berupa rumput berumpun. Tanaman pertanian kuno ini berasal dari dua benua, yaitu Asia dan Afrika Barat tropis dan subtropis. Bukti sejarah memperlihatkan bahwa penanaman padi di Zheijiang (Cina) sudah dimulai pada 3.000 tahun SM. Fosil butir padi dan gabah ditemukan di Hastinaput Uttar Pradesh India sekitar 100-800 SM. Selain Cina dan India, beberapa wilayah asal padi adalah Bangladesh Utara, Burma, Thailand, Laos, Vietnam (Nashshar, 2009).

Padi umumnya merupakan tanaman yang sensitif terhadap hama dan penyakit. Di Indonesia kombinasi antara iklim tropis, varietas, dan ketersediaan tanaman padi sepanjang tahun sangat cocok untuk perkembangan hama dan penyakit. Suhu dan kelembaban iklim tropis tidak banyak bervariasi dan berada pada rentangan kebutuhan optimum untuk perkembangan banyak hama dan penyakit padi. Hama padi dapat dibedakan menjadi hama utama dan hama bukan utama. Hama utama padi ialah hama yang memiliki daya rusak besar, tersebar luas secara merata, serta menurunkan hasil besar. Contoh hama utama padi yaitu tikus (Purwantoro, 2011).

Tikus termasuk hama yang sangat penting untuk dibasmi bukan saja pada tanaman padi, tetapi juga pada tanaman lain seperti jagung, ubi jalar, ubi kayu, kacang tanah, dan kedelai. Tikus bukan saja merusak tanaman yang masih di lapangan, tetapi juga hasil tanaman yang disimpan. Tikus sawah aktif pada malam hari. Tikus datang ke persawahan tiap saat, sejak dari persemaian sampai saat padi siap dipanen. Pada saat padi masih muda, tikus umumnya menyerang batang dan juga daun. Pada saat fase generatif, maka yang jadi incaran ialah butir 
gabah. Kalau tidak menyerang ke sawah, tikus biasanya tinggal dalam lubang-lubang yang ada di pematang atau tanggul. Tikus merupakan hama yang cepat berkembang biak, mudah menyesuaikan diri, dan memiliki mobilitas yang tinggi. Waktu birahinya singkat, yaitu kurang dari satu minggu setelah melahirkan. Usaha pengendalian tikus sangat kompleks. Dari segi teknis banyak cara-cara pengendalian, termasuk cara pemagaran, menggunakan buah mengkudu atau dengan menggunakan perangkap (Nashshar, 2009).

Untuk menghindari pertumbuhan dan perkembangan tanaman padi agar tidak terhambat maka kondisi lingkungannya perlu diperhatikan khususnya air. Padi merupakan tanaman yang membutuhkan air terus-menerus apalagi saat musim kemarau. Maka, ada baiknya digunakan pola pengairan yang baik agar padi dapat berproduksi sesuai dengan potensi genetiknya. Kebutuhan air dan genangan untuk tanaman padi sawah tergantung dari kebutuhan dan usia tanaman. Pada kondisi tergenang air, tanaman padi mendapatkan dua keuntungan yaitu pertumbuhan maksimal dan banyak jenis gulma yang tertekan, misalnya gulma rumputan dan tekian, sedangkan gulma berdaun lebar tidak begitu tertekan pertumbuhannya. Penggenangan sawah merupakan cara yang paling efektif untuk pengendalian gulma. Sebagian besar populasi jenis gulma akan menurun seiring dengan meningkatnya kedalaman air (Pramudyana dan Jufry, 2006).

\section{BAHAN DAN METODE}

Penelitian ini dilaksanakan didesa Singali, kecamatan Padangsidimpuan Hutaimbaru, kota Padangsidimpuan, dengan ketinggian tempat lebih kurang dari 500 m diatas permukaan laut.

\section{METODE PENELITIAN}

Penelitian ini dilakukan dengan menggunakan Rancangan Split Plot dengan 2 faktor yang ditelitiFaktor Peranan Pola Pengairan disimbolkan dengan (P) terdiri dari 3 taraf yaitu : Macak-macak $\left(\mathrm{P}_{1}\right)$, digenangi 2,5 cm $\left(\mathrm{P}_{2}\right)$, intermitten (pengairan berselang)( $\left.\mathrm{P}_{3}\right)$.Faktor Metode Pengendalian Hama Tikus disimbolkan (M) terdiri dari 3 taraf yaitu Pemagaran $\left(\mathrm{M}_{0}\right)$ Menggunakan buah mengkudu $\left(\mathrm{M}_{1}\right)$ Perangkap $\left(\mathrm{M}_{2}\right)$ 
Model linier dari rancangan ini adalah :

$Y_{i j k}=\mu+\alpha_{i}+\beta_{j}+(\alpha \beta)_{i j}+\delta_{i k}+\varepsilon_{i j k}$

Dimana :

$\mathrm{Y}_{\mathrm{i} \mathrm{k} \mathrm{k}}=$ nilai pengamatan pada taraf ke i faktor $\mathrm{P}$, taraf ke $\mathrm{j}$ faktor $\mathrm{M}$ dan ulangan ke $\mathrm{k}$.

$\mu \quad=$ nilai tengah umum

$\alpha_{\mathrm{i}} \quad=$ pengaruh taraf ke i dari faktor $\mathrm{P}$

$\beta_{\mathrm{j}} \quad=$ pengaruh taraf ke $\mathrm{j}$ dari faktor $\mathrm{M}$

$(\alpha \beta)_{\mathrm{ij}}=$ pengaruh interaksi taraf ke i faktor $\mathrm{P}$ dengan taraf ke $\mathrm{j}$ faktor $\mathrm{M}$

$\delta_{\mathrm{ik}} \quad=$ pengaruh acak untuk petak utama

$\varepsilon_{\mathrm{ijk}}=$ pengaruh acak untuk anak petak. (Gomez, 1995)

\section{Variabel Pengamatan}

Tinggi Tanaman (cm), Intensitas Serangan , Berat Gabah Per Rumpun (gr), Berat Gabah Per Plot (kg),

HASIL

Berdasarkan hasil analisis statistik terhadap variabel pengamatan Tinggi Tanaman $(\mathrm{cm})$, Intensitas Serangan, Berat Gabah Per Rumpun (gr), Berat Gabah Per Plot (kg).

Tabel 1. Hasil Interaksi Peranan Pola Pengairan Dan Metode Pengendalian Hama tikus Terhadap Tinggi tanaman

\begin{tabular}{lllll}
\hline Perlakuan & \multicolumn{4}{l}{ Umur tanaman/ cm } \\
\cline { 2 - 5 } & $3 \mathrm{mst}$ & $5 \mathrm{mst}$ & $7 \mathrm{mst}$ & $9 \mathrm{mst}$ \\
\hline P1M0 & $35,78 \mathrm{a}$ & $67,63 \mathrm{a}$ & $82,50 \mathrm{a}$ & $99,25 \mathrm{a}$ \\
P1M1 & $36,63 \mathrm{a}$ & $64,52 \mathrm{a}$ & $83,93 \mathrm{a}$ & $100,15 \mathrm{a}$ \\
P1M2 & $35,37 \mathrm{a}$ & $62,23 \mathrm{a}$ & $81,68 \mathrm{a}$ & $98,38 \mathrm{a}$ \\
P2M0 & $35,60 \mathrm{a}$ & $67,42 \mathrm{a}$ & $84,72 \mathrm{a}$ & $99,18 \mathrm{a}$ \\
P2M1 & $34,58 \mathrm{a}$ & $63,70 \mathrm{a}$ & $79,77 \mathrm{a}$ & $99,30 \mathrm{a}$ \\
P2M2 & $34,15 \mathrm{a}$ & $63,38 \mathrm{a}$ & $80,15 \mathrm{a}$ & $98,98 \mathrm{a}$ \\
P3M0 & $32,76 \mathrm{a}$ & $62,47 \mathrm{a}$ & $82,68 \mathrm{a}$ & $97,98 \mathrm{a}$ \\
P3M1 & $34,52 \mathrm{a}$ & $66,68 \mathrm{a}$ & $81,37 \mathrm{a}$ & $97,85 \mathrm{a}$ \\
\hline P3M2 & $34,81 \mathrm{a}$ & $66,74 \mathrm{a}$ & $80,70 \mathrm{a}$ & $99,32 \mathrm{a}$ \\
\hline
\end{tabular}

Keterangan : Angka yang diikuti oleh huruf yang sama pada kolom dan baris menunjukkan pengaruh tidak nyata menurut uji DMRT 5\%.

Tabel 2. Hasil Interaksi Peranan Pola Pengairan Dan Metode Pengendalian Tikus Terhadap Intensitas Serangan

\begin{tabular}{|l|l|l|l|l|l|}
\hline \multirow{2}{*}{ Perlakuan } & \multicolumn{4}{l|}{ Umur tanaman } \\
\cline { 2 - 6 } & $9 \mathrm{mst}$ & $10 \mathrm{mst}$ & $11 \mathrm{mst}$ & $12 \mathrm{mst}$ & $13 \mathrm{mst}$ \\
\hline P1M0 & $0,00 \mathrm{e}$ & $34,00 \mathrm{c}$ & $121,67 \mathrm{e}$ & $104,00 \mathrm{~b}$ & $103,00 \mathrm{c}$ \\
\hline P1M1 & $51,00 \mathrm{~b}$ & $121,67 \mathrm{~b}$ & $209,67 \mathrm{ab}$ & $204,50 \mathrm{a}$ & $213,33 \mathrm{a}$ \\
\hline
\end{tabular}




\begin{tabular}{|l|l|l|l|l|l|}
\hline P1M2 & $34,00 c$ & $103,67 \mathrm{bc}$ & $204,00 \mathrm{bc}$ & $205,83 \mathrm{a}$ & $198,00 \mathrm{ab}$ \\
\hline P2M0 & $17,00 \mathrm{e}$ & $102,33 \mathrm{bc}$ & $157,00 \mathrm{~d}$ & $177,00 \mathrm{ab}$ & $123,00 \mathrm{bc}$ \\
\hline P2M1 & $102,33 \mathrm{ba}$ & $210,33 \mathrm{a}$ & $214,67 \mathrm{ab}$ & $213,33 \mathrm{a}$ & $207,33 \mathrm{ab}$ \\
\hline P2M2 & $120,00 \mathrm{a}$ & $205,00 \mathrm{a}$ & $236,33 \mathrm{ab}$ & $252,67 \mathrm{a}$ & $195,67 \mathrm{ab}$ \\
\hline P3M0 & $17,00 \mathrm{de}$ & $102,33 \mathrm{bc}$ & $176,67 \mathrm{~cd}$ & $180,33 \mathrm{ab}$ & $184,33 \mathrm{ab}$ \\
\hline P3M1 & $68,67 \mathrm{~d}$ & $201,67 \mathrm{a}$ & $242,67 \mathrm{a}$ & $244,00 \mathrm{a}$ & $237,50 \mathrm{a}$ \\
\hline P3M2 & 85,33 & $220,67 \mathrm{a}$ & $212,33 \mathrm{ab}$ & $241,00 \mathrm{a}$ & $231,33 \mathrm{a}$ \\
\hline
\end{tabular}

Keterangan : Angka yang diikuti oleh huruf yang sama pada kolom dan baris menunjukkan pengaruh tidak nyata menurut uji DMRT 5\%.

Tabel 3. Rataan Berat Gabah Per Rumpun (gr) Akibat Perlakuan Pola Pengairan Dan Metode Pengendalian Tikus

\begin{tabular}{|l|l|l|l|l|}
\hline \multirow{2}{*}{ Pola Pengairan } & \multicolumn{3}{|l|}{ Metode Pengendalian } & \multirow{2}{*}{ Rataan } \\
\cline { 2 - 4 } & M0 & M1 & M2 & \\
\hline P1 & 33,58 a & $39,33 a$ & 29,76 a & 34,22 \\
\hline P2 & $37,50 a$ & 37,16 a & 36,29 a & 36,98 \\
\hline P3 & $28,83 a$ & 20,50 & $24,25 a$ & 24,52 \\
\hline Rataan & 33,30 & 32,33 & 30,10 & - \\
\hline
\end{tabular}

Keterangan : Angka yang diikuti oleh huruf yang sama pada kolom dan baris menunjukkan pengaruh tidak nyata menurut uji DMRT 5\%

Tabel 4. Rataan Berat Gabah Per Plot (kg) Akibat Perlakuan Pola Pengairan Dan Metode Pengendalian Tikus

\begin{tabular}{|l|l|l|l|l|}
\hline \multirow{2}{*}{ Pola Pengairan } & \multicolumn{3}{|l|}{ Metode Pengendalian } & \multirow{2}{*}{ Rataan } \\
\cline { 2 - 4 } & M0 & M1 & M2 & \\
\hline P1 & $1,50 \mathrm{ab}$ & $0,90 \mathrm{bc}$ & $1,21 \mathrm{bc}$ & 0,87 \\
\hline P2 & $2,13 \mathrm{a}$ & $1,38 \mathrm{ab}$ & $1,58 \mathrm{ab}$ & 1,69 \\
\hline P3 & $1,75 \mathrm{ab}$ & $1,28 \mathrm{ab}$ & $0,86 \mathrm{c}$ & 1,29 \\
\hline Rataan & 1,79 & 1,18 & 1,21 & - \\
\hline
\end{tabular}

Keterangan : Angka yang diikuti oleh huruf yang sama pada kolom dan baris menunjukkan pengaruh tidak nyata menurut uji DMRT 5\%

Berdasarkan hasil analisis secara statistik bahwa pengamatan tinggi tanaman menunjukkan pengaruh yang tidak nyata akibat pola pengairan dan metode pengendalian tikus pada setiap umur pengamatan yaitu 3 mst, 5 mst, 7 mst dan 9 mst, begitu juga dengan interaksi kedua perlakuan tersebut menunjukkan pengaruh yang tidak nyata pada setiap umur pengamatan.

Perlakuan pola pengairan menunjukkan pengaruh yang tidak nyata disebabkan oleh perlakuan dan faktor lingkungan. Faktor perlakuan yaitu terdapat beberapa pola pengairan yang berbeda akan tetapi perbedaan pola pengairan tersebut tanaman padi masih bisa tumbuh dan perbedaan tinggi tanaman tiap perlakuan yang dibuat tidak terlalu tinggi. Hal ini sejalan dengan penjelasan (Jufry, 2006) menjelaskan secara alami tanaman padi sawah dapat tumbuh 
dengan baik pada berbagai kedalaman genangan air sampai pada kondisi tidak tergenangi (macak-macak).

Metode pengendalian tikus juga menunjukkan pengaruh yang tidak nyata terhadap pengamatan tinggi tanaman hal ini disebabkan karena adanya sistem tanam yang tidak serentak pada sekitar areal penelitian sehingga tikus akan menyerang tanaman padi yang sudah keluar malai sebagaiman yang dijelaskan oleh (Purwantoro, 2011) serangan berat yang diakibatkan oleh tikus adalah pada saat fase generatif.saat fase generatif.

Interaksi kedua perlakuan yaitu pola pengairan dan metode pengendalian tikus memberikan pengaruh yang tidak nyata hal ini disebabkan curah hujan dan sitem tanam yang tidak serentak. Curah hujan pada fase vegetatif tanaman padi cukup tinggi sehingga setiap perlakuan sering tergenang air menyebabkan tinggi tanaman padi tidak berbeda jauh. Tinggi tanaman padi teringgi pada umur 9 mst pada perlakuan $\mathrm{P}_{3} \mathrm{M}_{1}=$ pola pengairan intermitten dengan metode pengendalian menggunakan buah mengkudu $(100,15)$ tinggi tanaman terendah pada umur 3 mst pada perlakuan $\mathrm{P}_{1} \mathrm{M}_{1}=$ pola pengairan Macak- macak dengan metode pengendalian menggunakan buah mengkudu $(32,76)$.

Dari hasil analisis statistik bahwa pola pengairan dan metode pengendalian tikus serta interaksi kedua perlakuan tersebut menunjukkan pengaruh yang nyata pada setiap umur pengamatan.

Hal ini disebabkan karena pada masing-masing perlakuan pola pengairan terjadi serangan tikus. Pola pengairan intermitten karena kondisi airnya bergantian digenangi air dan dikeringkan membuat tikus menyerang padi pada saat digenangi dan sebaliknya pada saat kondisi air dikeringkan tikus akan bersembunyi di lobang pematang sawah. Apalagi pada saat digenangi air 2,5 hingga $5 \mathrm{~cm}$ tikus akan mudah mengoyak batang padi kemudian memotongnya.

Metode pengendalian tikus memberikan pengaruh yang nyata. Hal ini disebabkan oleh bau busuk yang menyengat dari buah mengkudu yang menyebabkan tikus akan sulit bernafas 
sehingga tikus akan menjauh bahkan ada yang mati. Kemudian pemagaran yang dilakukan membuat tikus tidak bisa masuk karena tanaman sudah dikelilingi oleh pagar plastik dan perangkap dengan umpan pisang yang diberi racun timex didalamnya membuat tikus jera untuk mendekati petakan sawah.

Pengaruh yang nyata akibat interaksi kedua perlakuan disebabkan karena dengan air yang tergenang menimbulkan tikus akan muncul dan menyebabkan serangan. Dengan dibuatnya metode pengendalian tikus dengan pemagaran menyebabkan tikus tidak bisa masuk ke petakan sawah, dan metode menggunakan buah mengkudu akan mengganggu pernafasan tikus sehingga tikus akan menjauh. Kemudian menggunakan perangkap dengan umpan pisang yang diberi racun timex membuat tikus jera untuk mendekati petakan sawah tersebut. Pada pengairan macak-macak tikus tidak terlalu menyerang padi hal ini disebabkan karena tikus lebih suka menyerang padi dalam keadaan tergenang. Serangan tikus tertinggi pada umur 12 mst terdapat pada perlakuan $\mathrm{P}_{2} \mathrm{M}_{2}=$ pola pengairan digenangi dengan metode pengendalian Perangkap (252,67) dan serangan terendah pada umur 9 mst pada perlakuan $\mathrm{P}_{1} \mathrm{M}_{0}=$ Pola pengairan Macak-macak dengan metode pengendalian Pemagaran (0.00) atau tidak ada serangan.

Dari hasil analisis secara statistik pengaruh pola pengairan terhadap jumlah gabah berisi per rumpun menunjukkan pengaruh nyata, sedangkan pada perlakuan metode pengendalian tikus serta interaksi serangan terhadap jumlah gabah berisi per rumpun menunjukkan pengaruh yang tidak nyata.

Hal ini disebabkan karena pada saat padi berumur 7 mst dimana padi mulai berbunga dan membutuhkan air curah hujan cukup tinggi menyebabkan padi selalu tergenang. Ini sejalan dengan penjelasan (Prasetiyo, 2002) yang menjelaskan bahwa padi umur 55 hst sawah harus digenangi sampai pada masa berbunga serempak karena kekurangan air pada fase ini melemahkan pembentukan malai dan pembuahan sehingga butir gabah banyak yang hampa. 
Sedangkan pada metode pengendalian dan interaksi kedua perlakuan tersebut menunjukkan pengaruh yang tidak nyata disebabkan karena sistem tanam yang tidak serentak di sekitar tempat penelitian. Sehingga pada saat padi yang satu sudah panen tikus akan menyerang padi yang belum panen bahkan kesetiap metode pengendalian tikus.

Hal ini disebabkan karena pada fase padi berbunga padi sangat membutuhkan air untuk mendapatkan masa berbunga serempak dan pasa saat itu padi tergenangi air sehingga pembuahan padi menjadi berisi. sistem tanam yang tidak serempak membuat tikus menyerang padi pada setiap pola pengairan dan metode pengendaliannya.Pengaruh pola pengairan menunjukkan pengaruh nyata terhadap berat gabah per rumpun dan berat gabah per plot. Dan metode pengendalian tikus menunjukkan pengaruh nyata pada berat gabah per rumpun, sedangkan terhadap berat gabah per plot menunjukkan pengaruh tidak nyata. Begitu juga dengan interaksi dari kedua perlakuan tersebut menunjukkan pengaruh tidak nyata.

Hal ini disebabkan karena kondisi padi yang selalu tergenang air yang diakibatkan oleh curah hujan yang tinggi pada fase pembuahan (bunting) sehingga meningkatkan bakal butir gabah berisi. Sedangkan pada metode pengendaliannya tikus masih menyerang padi dalam setiap metode pengendalian yang diakibatkan oleh curah hujan yang tinggi sehingga padi tergenang dan umpan perangkap dan buah mengkudu yang digunakan terendam air dan hanyut dan sistem tanam yang tidak serentak. Interaksi dari kedua perlakuan tersebut adalah pola pengairan yang tergenang akan meningkatkan jumlah dan berat gabah berisi.

\section{KESIMPULAN}

Pada perlakuan pola pengairan menunjukkan pengaruh yang nyata terhadap pengamatan intensitas serangan pada setiap umur pengamatan yaitu 9 mst, 10 mst, 11 mst, 12 mstdan 13 mst, danterhadapjumlahgabahberisi per rumpun, berat gabah per rumpun dan berat gabah per plot.Pada perlakuan pola pengairan menunjukkan pengaruh tidak nyata terhadap pengamatan tinggi tanaman pada setiap umur pengamatan yaitu 3 mst, 5 mst, 7 mst dan 9 mst. Pada perlakuan metode pengendalian tikus menunjukkan pengaruh yang nyata terhadap 
pengamatan intensitas serangan setiap umur pengamatan berat gabah per plot. Menunjukkan pengaruh yang tidak nyata pada pengamatan tinggi tanaman setiap umur pengamatan dan berat gabah per rumpun.Pada perlakuan pola pengairan tanaman tertinggi pada perlakuan $\mathrm{P}_{3}$ (Intermitten) dan intensitas serangan tertinggi terdapat pada perlakuan $\mathrm{P}_{2}$ (digenangi). Perlakuan metode pengendalian tikus intensitas tertinggi adalah $\mathrm{M}_{2}$ (perangkap).

\section{SARAN}

Berdasarkan hasil penelitian ini disarankan melakukan pola pengairan intermitten dan metode pengendalian tikus menggunakan pagar plastik dan buah mengkudu.

\section{DAFTAR PUSTAKA}

AAK, 1993. Budidaya Tanaman Padi. Yogyakarta . Kanisius.

Adiratma, E. Roekasah. 2004. Stop Tanam Padi, Penebar Swadaya. Bogor.

Ali, Hanafiah,M.S. Dr. Ir. Kemas.2008. Rancangan Percobaan Aplikatif. Raja Grafindo Persada. Jakarta.

Ami, Anisa, 2011.Serba - Serbi Tanaman Padi. Alfarisi Putra. Bandung.

Jufry dan Pramudiani. 2006. Sistem Pengairan Padi Sawah. Penebar Swadaya. Jakarta.

Kahono, P. C. dan Pracaya, 2011. Kiat Sukses Budidaya Padi. Maraga Borneo Tarigas. Jakarta.

Nashshar, F. M. 2009. Pertanian Organik. Walatra. Bandung.

Purnamawati, M. Sc. Agr,Ir. Heni dan Purwono, MS, Ir. 2007. 8 Jenis Tanaman Pangan Unggul. Penebar Swadaya. Bogor.

Sastrapradja, Setijati D. 2012. Perjalanan Panjang Tanaman Indonesia. Pustaka Obor Indonesia. Jakarta.

Setyono, Agus dan Suparyono. 1993. Padi. Penebar Swadaya. Jakarta.

Tjahjadi, Ir. Nur. 1989. Hama dan Penyakit Tanaman. Kanisius. Palembang.

Tjahjono M. Agr, Ir. Budi dan Sakti Harahap, Ir. Idham. 1992. Pengendalian Hama Penyakit Padi. Penebar Swadaya. Jakarta.

Yandianto. 2003. Irigasi. Agro Media Pustaka. Bandung. 